\title{
Factors influencing the development of serum precipitins to farmer's lung antigen in Quebec dairy farmers
}

\author{
YVON CORMIER, JACQUES BÉLANGER, PIERRE DURAND
}

From the Centre de Pneumologie de l'Hôpital Laval, and the Département de Médecine Communautaire, Université Laval, Ste-Foy, Quebec, Canada

ABSTRACT A total of 888 randomly selected dairy farmers participated in an epidemiological study to evaluate the prevalence of precipitins to farmer's lung antigens, and the socioeconomic factors associated with their presence. Precipitins were present in 75 farmers $(8.4 \%)(65$ to Micropolyspora faeni, seven to Aspergillus spp, two to both Aspergillus and Micropolyspora faeni, and one to Aspergillus and Thermoactinomyces vulgaris). The titres ranged from a dilution of $1 / 32$ to a concentration of $\times 2$ (Ouchterlony's double diffusion method). In the study population there were 544 who had never smoked, 146 ex-smokers, and 198 smokers. Sixty nine precipitin positive subjects were either never smokers or ex-smokers; only six were smokers. The negative relationship between cigarette smoking and precipitins was highly significant $(\mathrm{p}=$ 0.004). Factors positively associated with positive precipitin reactions were: size of farm, time spent in the barn, and the presence of a family member previously diagnosed as having farmer's lung disease. Interestingly, positive precipitin reactions were not associated with any of the following: use of silos, hay conditioners, or hay dryers; the presence or quantity of mouldy hay; or the presence of respiratory symptoms. It is concluded that precipitin analysis is not useful as a screening method for farmer's lung, though it can be of diagnostic value in acute farmer's lung disease.

Farmer's lung is a common expression for an extrinsic allergic alveolitis related to the working conditions of farmers. Bacteria and fungi seen mostly in mouldy hay are the responsible allergens. Most farmers with this disease have serum precipitins against the common mouldy hay bacteria Micropolyspora faeni, Thermoactinomyces vulgaris, and different Aspergillus fungi.

Previous studies have shown that from $3 \%$ to $30 \%$ of symptomless dairy farmers have positive precipitin reactions to farmer's lung antigens. ${ }^{1-3}$ Some factors associated with these precipitins have previously been identified. For example, smokers are less likely to have positive precipitin reactions. ${ }^{45}$ Recently we have shown, by bronchoalveolar lavage, that some of these seropositive symptomless

Address for reprint requests: Dr Yvon Cormier, Centre de Pneumologie, Hôpital Laval, 2725, chemin Ste-Foy, Ste-Foy, Quebec G1V 4G5, Canada.

Accepted 15 October 1984 farmers have a subclinical alveolitis. ${ }^{6}$ A similar observation has been made in normal individuals with positive precipitins to bird fancier's antigens. ${ }^{78}$ Possibly patients who develop extrinsic allergic alveolitis come from this pool of seropositive subjects. Identification of all possible factors associated with positive precipitin reactions could therefore be of major importance in the prevention of farmer's lung.

The objective of the study was to evaluate the influence of some host and environmental factors on the prevalence of positive precipitin reactions in dairy farmers.

\section{Methods}

SELECTION OF SUBJECTS

We obtained the official list of dairy farmers from the Quebec Department of Agriculture for the six rural counties within a radius of $80 \mathrm{~km}$ from Quebec city. This list included 3596 farms, from which we randomly selected groups of 20-30 farms, on a 
geographical basis, to cover the entire territory. Selected farm owners were then informed, by letter, that a nurse would visit them and were asked to participate to the study. At each farm each subject who spent at least one hour in the barn each winter day, and for whom farming was the major occupation, was included in the study. For each subject the nurse filled in a questionnaire and drew a blood sample for precipitin analysis. All selected subjects were visited in the winter months from 15 January to 30 March. We enrolled 387 subjects in 1980 and 501 in 1981 . Only four solicited individuals refused to participate to the study.

\section{QUESTIONNAIRE}

The questionnaire used was adapted from the American Thoracic Society standardised questionnaire for epidemiological studies, ${ }^{9}$ specific questions for this study being added. Some of these questions concerned the farming itself (the size of farm, methods of hay making and storage used, and quality of hay). Other questions were directed towards the farmer's life habits and included the number of years lived on a farm and the number of hours spent in the barn daily during winter. A detailed tobacco history was taken and the number of pack years determined. Definitions of smokers, ex-smokers, and never-smokers were those of the American Thoracic Society in the epidemiology standardisation project." Smokers were subjects who had smoked at least one cigarette a day for one year; ex-smokers were subjects who had ceased smoking for at least one month before the study; never smokers were farmers with a tobacco history of less than 20 packs of cigarettes in a lifetime.

Precipitin analysis was done by the double diffusion method of Ouchterlony. ${ }^{10}$ Serum was concentrated two fold by refilling the well after a first diffusion; for a four fold concentration the well was refilled three times. Serum was considered negative only if there was no precipitin seen at a concentration up to four fold. Antigens tested were $T$ vulgaris and $M$ faeni (Greer laboratories) and three strains of Aspergillus fumigatus (strains 3 and 5 from Greer laboratories and strain 6 from Bencard). All precipitin positive subjects were invited to our institution for further analysis. A complete medical history and physical examination was undertaken in these subjects followed by chest radiography and pulmonary function tests (spirometry, and determination of lung volumes, diffusion capacity, and airway resistance).

DATA ANALYSIS

Subjects were divided into groups according to their smoking habits and the size of the farm where they worked. Farms were divided into three groups: small- $<50$ head of cattle; medium $-50-75$ heads; and large $\longrightarrow>75$ heads.

A $\chi^{2}$ test was performed in every case where comparisons were to be made. The Yates's correction was applied when one cell had an expected frequency of less than 10 . Contingency tables were further subdivided to eliminate the influence of smoking and barn contact on the results.

\section{Results}

In most farms cattle were fed by hand with baled hay not older than one year; in 280 out of 888 instances silage was also used ( 208 hay and 72 corn). Forty seven per cent $(415)$ of the subjects said that their hay was not mouldy; $43 \%$ (382) answered that there was little moulding ( $1-5 \%$ of the hay); $6 \%$ (57) answered that there was a fair amount of mouldy hay (6-10\% of the hay); finally, $4 \%$ (34) said that their hay had appreciable moulding (11-30\% of the hay); all these last 34 subjects were questioned in the winter of 1981 . When asked about preventive methods, $75.2 \%$ of the farmers responded that they had a hay conditioner, $57 \%$ had a hay dryer, and $52 \%$ had both. The Quebec country weather charts for the past 30 years show 220-250 hours of sunshine in a summer month, $11.4 \mathrm{~cm}$ of rain, and a relative humidity of $56-87 \%$.

Data were collected over two winter periods, during which we enrolled 888 farmers out of the 892 solicited. Of the 888 farmers, there were 595 men (mean (SD) age 41.7 (15.4) years) and 293 women (mean age $40 \cdot 2(10.4)$ years). The great majority of females had never smoked $(83 \%)$, while $51 \%$ of the men had never smoked. We found positive serum precipitins in 75 subjects (65 to Micropolyspora faeni, seven to Aspergillus spp, two to both Aspergillus and Micropolyspora faeni, and one to Aspergillus and Thermoactinomyces vulgaris).

Those who had never smoked had a higher prevalence of positive precipitin reactions than smokers, while ex-smokers were intermediate. This association was highly significant, with a $\chi^{2}$ of 11.0 and $\mathrm{p}=0.004(\mathrm{fig}, a)$. Farm size also influenced the prevalence of positive precipitins. Subjects working on larger farms were more likely to have positive reactions than those working on smaller farms $\left(\chi^{2}=\right.$ $11 \cdot 0, p=0.0041 ; f i g, b)$. The duration of daily exposure to the barn had a similar influence on the likelihood of precipitins $\left(\chi^{2}=6.64, p=0.01\right.$; fig, $\left.c\right)$. This relationship was not due to difference in smoking history. Six hundred and fifty nine out of the 888 subjects spent more than three hours in the barn; of these more exposed subjects, there were 161 smokers $(81 \%$ of total smokers), 124 ex-smokers $(85 \%$ 


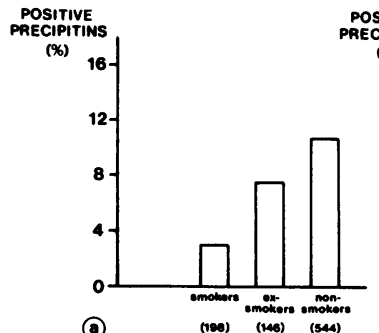

(a)

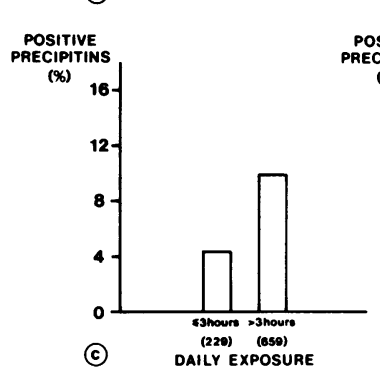

IVE

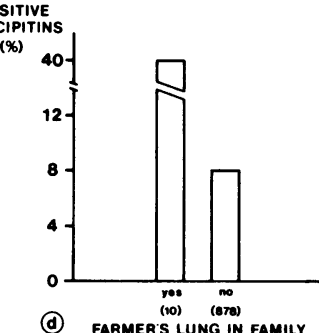

Relationship between presence of precipitins to farmer's lung antigens and (a) smoking history; (b) farm size as indicated by number of cattle; (c) daily exposure in the barn; (d) farmer's lung in a family member. Numbers in parentheses are the total number of subjects in each group.

of total ex-smokers) and 374 non-smokers (69\% of total non-smokers). Thus a smaller proportion of non-smokers spent more than three hours in the barn $\left(\chi^{2}=22.46, p<0.01\right)$.

Women had a lower prevalence of positive precipitin reactions than men $\left(5.5 \%\right.$ and $9.9 \% ; \chi^{2}=$ $5.04, p=0.0248$ ) and spent less time in the barn than the men; only 140 out of 293 females $(48 \%)$ spent more than three hours in the barn, compared with 519 out of 595 men $(87 \%)\left(\chi^{2}=159.6, p<\right.$ $0.001)$. The prevalence of positive precipitin reactions was higher in subjects with a family member known to have had farmer's lung $\left(\chi^{2}=9 \cdot 22, \mathrm{p}=\right.$
$0.0024 ;$ fig, $d)$. Of the more exposed farmers, there were 169 out of $198(85 \%)$ workers in the largest farms (more than 75 heads of cattle); 190 out of 234 $(81 \%)$ workers in farms with 51-75 heads of cattle and 300 out of $456(66 \%)$ workers in farms with less than 50 head of cattle. Thus a higher proportion of farmers on larger farms spent more than three hours in the barn $\left(\chi^{2}=35.71, \mathrm{p}<0.001\right)$.

None of the other variables studied was associated, either positively or negatively, with the finding of serum precipitins against farmer's lung antigens. These included respiratory symptoms suggestive of farmer's lung (dyspnoea, wheezing, number of colds); age $\left(\chi^{2}=7 \cdot 40, \mathrm{p}=0 \cdot 116\right)$; number of years on a farm $\left(\chi^{2}=2.79, p=0.095\right)$; methods of hay making and storage and the quality of hay $\left(\chi^{2}=\right.$ $0 \cdot 85, \mathrm{p}=0 \cdot 357$ ).

When the three main respiratory symptomscough and sputum for at least three months a year and dyspnoea-were regrouped in the same table, $245(28 \%)$ subjects were found to have at least one symptom. Twenty nine per cent of the seronegative and only $17 \%$ of the seropositive subjects had symptoms $(p=0.038)$. This difference was probably due to the smaller number of smokers in the seropositive group: When the test was done on the never smoker subgroup (544 subjects) there was no association between serum precipitins and respiratory symptoms.

We carried out further statistical analysis on the never smoker subgroups (table 1) to control the influence of smoking on the results. Again we found more positive precipitin reactions among subjects who spent three hours or more (49 positives out of 374) than in subjects who spent less than three hours in the barn (only nine out of 161); $p=0.01$. The prevalence of positive precipitin reactions was still greater in men than in women $(p=0.002)$.

We computed separate contingency tables for the 229 subjects who spent less than three hours in the

Table 1 Contingency tables for the 544 farmers who had never smoked

\begin{tabular}{|c|c|c|c|c|}
\hline Symptoms & Normal & With symptoms & Total & Significance \\
\hline $\begin{array}{l}\text { Seronegative } \\
\text { Seropositive } \\
\text { Total }\end{array}$ & $\begin{array}{r}398 \\
50 \\
448\end{array}$ & $\begin{array}{r}88 \\
8 \\
96\end{array}$ & $\begin{array}{r}486 \\
58 \\
544\end{array}$ & $\begin{array}{l}\chi^{2}=0.66 \\
p=0.53\end{array}$ \\
\hline Daily exposure $(h)$ : & $<3$ & $\geqslant 3$ & Total & Significance \\
\hline $\begin{array}{l}\text { Seronegative } \\
\text { Seropositive } \\
\text { Total }\end{array}$ & $\begin{array}{r}161 \\
9 \\
170\end{array}$ & $\begin{array}{r}325 \\
49 \\
374\end{array}$ & $\begin{array}{r}486 \\
58 \\
544\end{array}$ & $\begin{array}{l}\chi^{2}=6.68 \\
p=0.01\end{array}$ \\
\hline Sex: & Male & Female & Total & Significance \\
\hline $\begin{array}{l}\text { Seronegative } \\
\text { Seropositive } \\
\text { Total }\end{array}$ & $\begin{array}{r}257 \\
43 \\
300\end{array}$ & $\begin{array}{r}229 \\
15 \\
244\end{array}$ & $\begin{array}{r}486 \\
58 \\
544\end{array}$ & $\begin{array}{l}\chi^{2}=9.47 \\
p=0.002\end{array}$ \\
\hline
\end{tabular}


Table 2 Contingency tables for the two categories of exposure

\begin{tabular}{|c|c|c|c|c|c|}
\hline \multirow{2}{*}{$\begin{array}{l}\text { Daily exposure }(h) \text { : } \\
\text { No of cattle }\end{array}$} & \multicolumn{2}{|l|}{$<3$} & \multicolumn{2}{|l|}{$\geqslant 3$} & \multirow[b]{2}{*}{ Total } \\
\hline & $0-49$ & $\geqslant 50$ & $0-49$ & $\geqslant 50$ & \\
\hline $\begin{array}{l}\text { Seronegative } \\
\text { Seropositive } \\
\text { Total }\end{array}$ & \multicolumn{2}{|c|}{$\begin{array}{l}148 \\
8 \\
156 \\
\chi^{2}=0 \cdot 228, p=0.63^{71}\end{array}$} & \multicolumn{2}{|c|}{$\begin{array}{lr}275 & 319 \\
25 & 40 \\
300 & \\
\chi^{2}=1 \cdot 45, p=0.23^{359}\end{array}$} & $\begin{array}{r}813 \\
75 \\
888\end{array}$ \\
\hline Years on farm: & $<10$ & $\geqslant 10$ & $<10$ & $\geqslant 10$ & Total \\
\hline $\begin{array}{l}\text { Seronegative } \\
\text { Seropositive } \\
\text { Total }\end{array}$ & \multicolumn{2}{|c|}{$\begin{array}{rr}185 & 34 \\
8 & 2 \\
193 & 36 \\
\chi^{2}=0.0041, p=0.95\end{array}$} & \multicolumn{2}{|c|}{$\begin{array}{rr}498 & 96 \\
61 & 4 \\
559 & 100 \\
\chi^{2}=3 \cdot 81, p=0 \cdot 051\end{array}$} & $\begin{array}{r}813 \\
75 \\
888\end{array}$ \\
\hline Sex: & Male & Female & Male & Female & Total \\
\hline $\begin{array}{l}\text { Seronegative } \\
\text { Seropositive } \\
\text { Total }\end{array}$ & $\begin{array}{r}71 \\
5 \\
76 \\
\chi^{2}=\end{array}$ & $\begin{array}{r}148 \\
5 \\
153 \\
42\end{array}$ & $\begin{array}{l}465 \\
54 \\
519 \\
\chi^{2}=0\end{array}$ & $\begin{array}{r}129 \\
11 \\
140\end{array}$ & $\begin{array}{r}813 \\
75 \\
888\end{array}$ \\
\hline
\end{tabular}

barn and the 659 who spent three hours or more (table 2). Chi square tests showed no difference between men and women for the presence of precipitins $(p>$ $0 \cdot 3$ ); there was no difference between smaller farms (0-49 head of cattle) and larger farms with 50 or more heads ( $p>0.2$ ); there was no relationship between length of service on the farm (more than 10 years or 10 years or less) and the presence of precipitins $(p>0.05)$. The 10 subjects who had a family member diagnosed as having farmer's lung were all in the more exposed group, and the association between heavy exposure and presence of precipitins remained significant $(p=0 \cdot 007)$.

Six subjects answered "yes" to the question about past farmer's lung. Of these two had positive precipitin reactions and four did not. Of the 56 seropositive subjects who were further investigated, only four had a history suggestive of previous farmer's lung. Medical records obtained for two of these confirmed the diagnosis.

\section{Discussion}

In order to have the most homogeneous population of farmers possible we chose only dairy farmers. Our randomisation procedure was designed to cover the whole territory selected. We used sampled groups of farms instead of individual farms for obvious logistic reasons. All subjects participated in the study during the winter months. Although country travelling is more difficult in winter, this season was advantageous because farmers were more likely to be at home and to have time to participate in the study. We had a very high participation rate, with only four refusals. Winter is also the season of antigenic contact, and this may have helped to identify subjects with low titres of precipitins who could have been nega- tive in the summer. All questions were administered by a trained nurse, which we think avoided misunderstanding and other problems inherent in a self administered questionnaire.

Our data show a prevalence of positive precipitin reactions of $8.4 \%$ among dairy farmers in rural communities surrounding Quebec city; this is similar to the prevalence found elsewhere, especially in the nearby state of Vermont. ${ }^{2}$ We found, like others, ${ }^{45}$ a very strong negative relationship between smoking and the prevalence of serum precipitins. Our finding of a higher prevalence of positive results in larger farms supports the recent data of Gruchow et $a^{5}$ and contradicts evidence from previous studies. We believe that this higher prevalence of precipitin positive subjects in larger farms is related to a longer daily contact with the antigens; farmers on larger farms spent more time in the barn than those on smaller farms.

Women were found to have a lower prevalence of precipitins to farmer's lung antigens than men even though they smoked less. This can be explained by the fact that they spent less time in the barn than men. When the less exposed group was separated from the more exposed there was no difference between men and women in the prevalence of precipitins. Thus a sex linked factor influencing the susceptibility to develop precipitins seems unlikely to be present.

As in the Wisconsin study, ${ }^{5}$ we found no increase in the prevalence of precipitins with age, neither was there any increase with the number of years spent on the farm. There were more seropositive individuals in the currently more exposed group, however, both for all subjects and for the group who had never smoked. The development of precipitins is therefore influenced more by the length of daily antigenic con- 
tact than by cumulative exposure. This effect is seen in other pathological conditions (for example, nonorganic pneumoconiosis).

From our results and those of Gruchow et $a^{5}$ it appears that methods of hay making, drying, and storage do not influence the prevalence of precipitins. Nevertheless, it is generally accepted that the quality of hay has an important influence on the prevalence of farmer's lung. " On the other hand, we found that the prevalence of precipitins was higher among farmers who had a family member previously diagnosed as having farmer's lung (fig, $d$ ). One explanation for this finding is that a genetic factor could influence sensitivity to hay. Alternatively, environmental factors might be of paramount importance in the development of sensitivity. We favour the second hypothesis for three reasons. Firstly, some cases of farmer's lung in the family of seropositive farmers were in the spouse, thus excluding a genetic influence; secondly, family members generally live on the same farm and are exposed to the same environment; and, thirdly, study of genetic markers such as HLA $^{12}$ failed to show a difference between patients and normal subjects.

The presence of precipitins in our study was useless as a mean of identifying farmer's lung, past or present. Of the 56 seropositive subjects we studied, four had had farmer's lung. Two out of these four and four seronegative subjects answered "yes" to the specific question on whether they had ever had farmer's lung. Some previous studies have come to the same conclusion ${ }^{13}$ but others have found a large incidence of farmer's lung in seropositive subjects. For example, Marx et al $^{14}$ found that $38 \%$ of subjects with positive precipitin reactions had a history suggestive of farmer's lung; Smyth et al ${ }^{15}$ could identify a large many subjects with farmer's lung by questionnaire alone. We believe that these discrepancies can be explained by differences in the criteria used to make the diagnosis. We conclude therefore that precipitin analysis is not useful as a screening method for farmer's lung. The presence of precipitins can, however, still be of diagnostic value in a patient with acute farmer's lung disease, where precipitin reactions are positive in up to $85 \%$ of cases.

We wish to thank Louis-Paul Rivest and Suzanne Gingras for their statistical advice. The study was supported by the Fondation JD Bégin, l'Université Laval; and YC had a scholarship from the Fonds de la Recherche en Santé du Québec.

\section{References}

1 Pepys J, Jenkins PA. Precipitin test in farmer's lung. Thorax 1965;20:21-35.

2 Gump DW, Babbott FL, Holly C, Sylwester DL. Farmer's lung disease in Vermont. Respiration 1979;37:52-60.

3 Roberts RC, Wenzel FJ, Emanuel DA. Precipitating ì antibodies in a midwest dairy farming population $\vec{\omega}$ toward the antigen associated with farmer's lung dis- $\omega_{\infty}$ ease. J Allergy Clin Immunol 1976;57:518-24.

4 Morgan DC, Smyth JT, Lister RW, et al. Chest symptoms in farming communities with special reference to farmer's lung. Br J Ind Med 1975;32:228-34.

5 Gruchow HW, Hoffman RG, Marx JJ, Emanuel DA, Rimm AA. Precipitating antibodies of farmer's lung antigens in a Wisconsin farming population. Am Rev Respir Dis 1981;124:411-5.

6 Solal-Céligny P, Laviolette M, Hébert J, Cormier Y. Immune reactions in the lungs of asymptomatic dairy farmers. Am Rev Respir Dis 1982;126:964-7.

7 Moore VL, Pedersen GM, Hauser WC, Fink JN. A study of lung lavage materials in patients with hypersensitivity pneumonitis: in vitro response to mitogen and $\bar{\partial}$ antigen in pigeon breeder's disease. $J$ Allergy Clin Immunol 1980;65:365-70.

8 Calvanico NJ, Ambegaonkar SP, Schlueter DP, Fink JN. Immunoglobulin levels in bronchoalveolar lavage fluid from pigeon breeders. J Lab Clin Med 1980;96:129-40.

9 Ferris BG. Epidemiology standardization project (July 1978). Am Rev Respir Dis 1978;118 suppl:1-120.

10 Ouchterlony O. Antigen-antibody reactions in gels. Acta Pathol Microbiol Scand 1953;32:231.

11 Grant IWB, Blyth W, Wardrop VE, Gordon RM, Pearson JCG, Mair A. Prevalence of farmer's lung in Scotland: a pilot survey. $\mathrm{Br}$ Med J 1972;i:530-4.

12 Terho EO, Koskimies S, Heinonen OP, Mantijarvi R. HLA and farmer's lung. Eur $J$ Respir Dis 1982;63:361-2.

13 Madsen D, Klock LE, Wenzel FJ, Robbins JL, Schmidt CD. The prevalence of farmer's lung in an agricultural population. Am Rev Respir Dis 1976;113:171-4.

14 Marx JJ, Emanuel DA, Dovenbarger WV, Reinecke N ME, Roberts RC, Treuhaft MW. Farmer's lung disease among farmers with precipitating antibodies to the $N$ thermophilic actinomycetes: a clinical and immunolog- N ical study. J Allergy Clin Immunol 1978;62:185-9.

15 Smyth JT, Adkins GE, Lloyd M, Moore B, McWhite E. Farmer's lung in Devon. Thorax 1975;30:197-203. 